Portland State University

PDXScholar

\title{
Mary: A Creative Biography of Mary Wollstonecraft Shelley through the Lens of Her Interpersonal Relationships
}

Julien-Pierre E. Campbell

Portland State University

Follow this and additional works at: https://pdxscholar.library.pdx.edu/honorstheses

Part of the Fiction Commons

Let us know how access to this document benefits you.

\section{Recommended Citation}

Campbell, Julien-Pierre E., "Mary: A Creative Biography of Mary Wollstonecraft Shelley through the Lens of Her Interpersonal Relationships" (2021). University Honors Theses. Paper 980.

https://doi.org/10.15760/honors.1004

This Thesis is brought to you for free and open access. It has been accepted for inclusion in University Honors Theses by an authorized administrator of PDXScholar. Please contact us if we can make this document more accessible: pdxscholar@pdx.edu. 


\section{Mary}

A Creative Biography of Mary Wollstonecraft Shelley

Through the Lens of her Interpersonal Relationships

By Julien-Pierre “JP” Campbell 


\section{Percy Shelley}

\section{June 1814}

Night falls slowly around us. The sky has rioted with all of God's colors and at last succumbed to the pale blue of the gloaming. He stares hard at the sky. Who can know the exact thoughts that are stirred behind that princely brow? His eyes bear the faraway look I've come to associate with brilliance. He's composing. Perhaps I stay quiet long enough -- Lord knows our sepulchral companions will -- he will speak verse. I'm sure I could observe him for rapturous eons. His cheeks are flushed and his curls are mussed. Such a beautiful man.

If Father knew we were here, at Mother's grave, no less...I hesitate to think what he'd say. He may mock my belief in the Lord, but surely he'd cry sin at this. Betrayal, perhaps, desecration. Mother's memory is the nearest to religion Father will ever follow. But I tell you, I have brought my Shelley here for a reason. There is no place in the world dearer to me, and no man more in possession of my heart. He is light, beauty. He is everything. I am sure if Mother were alive, she would encourage our love. She would call it no mere dalliance. I can only hope Father will forgive me my indiscretions when I tell him I love this man. It bears a similarity to his brilliant love affair with Mother. I can only hope.

At last, Shelley turns to me. His eyes are liquid starlight. "Mary." One word, one name, but the tenderest of emotions are felt. The word rushes from his lips in a burst of breath, but I swear all the emotions in the world are contained in it.

"Percy," I breathe back. 
His eyebrows raise, just slightly. I rarely refer to him by his Christian name. He smiles. His smile is so gentle I almost fear my heart will rend in two. "How beautiful and calm and free thou art," he says. His voice has taken on that melodious quality it has when he recites verse.

This poem, the masterwork sure to flow from his lips, is about me. I have never inspired anyone to verses of love. I feel I could die right here and be content all my days.

"In thy young wisdom, when the mortal chain/Of Custom thou didst burst and rend in twain," he continues. The words settle, crackling like flames, in the air around us. I breathe deep of the night air -- the perfume of summer hedgerows and mown grass is all but intoxicating.

My Shelley smiles sheepishly. "I must confess, my dear girl, that is all I've composed. Your beauty...silences me sometimes.”

God in heaven. What did I do to deserve these sweet words, these dear looks? I am Mary of the stern countenance and broad forehead. Mary of the lecture-hall speeches and passionate opinions. I am no romantic heroine, no fainting damsel men fall over themselves for. I am not becoming like Jane or demure like Fanny. And yet...with Shelley I feel as if I could be a heroine, or a becoming lady. I feel as if I could be anything. "Thank you," I say. "It is very beautiful."

"You are very beautiful," he returns.

I really do feel it. I feel brave and passionate and all but drunk. What pleasure it is to be sixteen and have the world open ahead of you like a ripe peach! "Mr. Shelley," I say carefully, “there is something I must tell you." I sneak a glance to Mother's grave. She would approve, I think. The stone bench under us still holds the heat of the day. I rest my hand on its rough surface, if only to anchor myself to something tangible.

"Oh?” A smile teases at his lips. 
I take a deep breath. I grab hold of his hand before I can stop myself. Instantly, the contact feels like magma in my veins. I am more than conscious that this is the first time I have touched him. All of these hours strolling through the city, sitting side by side at the supper table, discussing God and love and literature -- even then, we have not so much as brushed against one another. My Shelley is too much of a gentleman. He presses my hand so lightly that it feels like the touch of a feather. His hands are soft, uncalloused. His fingers are long, pale, almost feminine. Such attractive hands.

“Mr. Shelley, if I do not confess this now, I don't believe I ever will.” My voice is surprisingly firm. "What I mean to say is --" As soon as the thought occurs, my resolve melts like candle wax. Who am I to tell this poet I love him? This nobleman who is already joined to another? Who am I to forget poor Harriet, nettle in my side as she is? Unfair to Shelley, perhaps not understanding his genius, but spurned all the same. I look into his eyes. Blue and deep as oceans. Joy as boundless as this sky above us. "I love you," I blurt. I take his other hand, and press them to my chest. "I love you with all the ardor I possess. I love you madly. Feverishly. I don't believe I will ever love another as much as I do love you."

He is silent for an impossibly lengthy moment. His full lips are screwed in a thoughtful sort of grimace, his brow furrowed. I do not recognize this look. He is not composing, nor is he despairing, nor is he raging, nor is he joyful. I have seen all of these emotions flit fast as ships across his countenance. This expression, this...disgruntled...thoughtful...frustrated look, is unfamiliar. The magma in my veins has cooled to ice. This, I think, is where my Mr. Shelley will leave me. I was a lovely dalliance, he will say, and a delight to be around, really I was. But he is a married man, and a father. He is a grown man with the responsibilities of a noble. He is Sir 
Shelley in the eyes of his father. The daughter of an anarchist is simply unsuitable as a companion, much less a mistress, but I'll understand, won't I? I will be a good sport, won't I?

I grit my teeth and relax my grip on his hands. Perhaps I've bruised them. What an ugly thought! Oh, stupid Mary! Foolish heart! I am no lovelorn child. I am the daughter of Mary Wollstonecraft, and if she is peering down at me from heaven, she must be wringing her hands and gnashing her teeth at my sheer idiocy --

And then he is kissing me. He is kissing me and my hands are bunched in his shirt and I suppose I am kissing him back and his lips are as soft as his dear hands and I could die of love and --

He pulls back. He is looking at me once again with a look I am unfamiliar with. His eyes are kind, however. I know this. "My Mary," he says at last. "I love you."

"Say it again," I breathe.

He laughs, a joyous bark that echos off of the gravestones around us. It is out of place in such a solemn setting, but its jubilant sound is a balm to my soul. "I love you!" he shouts, leaping up. He throws his arms wide. "I love you, Mary Godwin! I love you!" He turns to the gravestones and cries, "Do you hear, you boney creatures? Hobgoblins and mischief-makers! Ghouls and phantoms! I love her!” I laugh, delighted. He sprawls down on the bench at my side and rests his head on my shoulder. "Well, Ms. Godwin, whatever shall we do about our love? How shall we proceed?"

I smirk. I can almost feel Mother's hands on my shoulders, hear her voice in my ear, giggling and encouraging. Mother believed staunchly in free love and disdained marriage. I decide, in this moment, that I shall do the same. "I would follow you to the ends of the earth, Mr. 
Shelley," I say honestly. "I will follow your lead as long as you allow. But for this one moment...I beseech you, sir, to follow mine.”

His eyes flash as I lay him down in the grass by Mother's grave.

He follows my lead until my head spins.

\section{2}

I have been many things in my life. I have been the child of revolutionaries. I have been a member of the "League of Incest," as they call us. I have been mother to children living and dead. I have been the subject of hushed whispers and jeers in the streets. I have been an author of great works and failed ones. I have been the mistress of a great poet. I have been a warning to young girls. I have been a muse. I have been hated. I have been so in love I saw stars. There is one thing I am not.

A fool.

I see the way Shelley looks at Jane Williams. I saw the way he looked at Claire. At Teresa. "Emilia," he renamed her, and she took to it like I once did. He writes his world like poetry. We are expected to speak and act as his characters. I have played the role he wrote into existence. I have had frolics of my own. Edward, the Prince -- they meant nothing compared to my Shelley. I engaged in these...acts because it pleased him. His guilt assuaged.

Does the poet feel guilt?

I certainly do. I dream of Harriet nightly. Harriet, drowned and seeking vengeance against the stumpret who robbed her of husband and life. I see her lifeless eyes each time I close my own. I see my children, dear and flush with life, beckoning me to them. My William of the fairy face and Clara of the dimpled cheeks. The little girl who went to the grave unnamed. Their 
hands grab at my skirts. "Mama," they wail, "Mama, join us." I see Fanny, quiet and sorrowful and blaming, ever blaming.

These visions haunt me waking and sleeping.

And Shelley? He moons over Jane Williams like a boy in love. He writes verse to her. $\mathrm{He}$ sings to her, reads aloud to her. They go sailing in that damnable boat. She spurns her husband's affections for Shelley's. I see this and am powerless against it.

There is no talking Shelley out of moves made at the direction of his heart. I was once Jane, young and beautiful and silly. Thrilled at his pretty words and enamored beyond reason. Jane is not at fault. She is lovely and kind, if not vapid. It is my husband, presenting as alluring and innocent of his faults. I cannot bring myself to rage at the circumstances. So I am cold to him. I shrug his advances off. I hide my hurt in a shroud of ice. There is no anger, only sadness bitter as gall.

What have I brought him? Three children, dead and buried? One live boy, sickly and pale? A novel infamous for the hatred others bear it? A father ever-begging him for money? A callous and uncaring wife?

I am not a fool. But I certainly live like one.

\section{Summer 1816}

It is a miserable summer. The air carries the chill of winter, there are gusts of wind that stink of ash, and the driving rain forces us to avoid the outdoors. Shelley has taken to pacing the halls of the villa like a caged tiger. My poor, brilliant love -- he values nature deeply. I know he longs to take lengthy rambles and go sailing. Baby William is sometimes feverish. He is needy and prefers my company to that of his father, which I believe stings Shelley's ego. I assure him 
once his son passes a year of age, he will toddle everywhere after Papa. This usually mollifies poor Shelley. William is a charming little fellow. He will often roll side to side for many minutes at a time, delighted at his movement. He lifts his head a bit now and then. He smiles and laughs often. It cheers me to think how happy my child is. I'm sure he will be a poet like his father, perhaps even a great one. I cannot know for sure, but I believe him gentle and easy of spirit. Would someone who will grow up cruel or simple grin and giggle so much? I think not.

Often I sit by the fire for hours rocking William. Percy writes at a frenetic pace, or talks at length with Byron. They seek to outmatch one another with ribald jokes and lewd stories. Byron is apparently quite impressed at William's bastardry. Ugly words. I like the man, but I do not care for his humor, nor for his eagerness to compete with Shelley. I think, privately, that men are sometimes silly as children. Byron's hounds have the run of the house, which overjoys William. He is frightened by the rest of the menagerie. I must admit, the sight of peacocks in the parlor and a badger sleeping by the hearth is arresting.

\section{XXX}

Yet another ungenial night. The sky is gray as slate and the rain taps on the roof incessantly. Claire is miserable and easily nettled. I think, frankly, she is wretched over Byron's rejection. She pines for him day and night, plying him with sweets, with songs, with poems. It's a pity.

“I am bored out of my skull,” Byron announces. "I believe I will die.” He certainly has a flare for the dramatic.

We are in front of the hearth once again. We've been sitting in companionable silence for the last hour or so, writing by candlelight, reading by firelight, watching the rain. William has fallen asleep on my lap. The fire casts light only on our little circle: Byron in his deep burgundy 
chair, a book open in his lap; Percy scribbling furiously at a poem, stretched feline on the floor; and myself and William and a volume of Milton's poetry in a pale green chair. The dogs lay about the room asleep. Byron's little chimp sits on the mantle, gazing at us owlishly. The little creature is rarely silent and still.

The room is richly carpeted with lovely damask drapes. I believe this room to be my favorite -- a place of camaraderie and creativity. Shelley at last turns from his writing and smirks at the baron.

"Out of your skull, yes?" he says, all mock-seriousness. "My dear man, you must be taken to a doctor at once. Shall I call for Polidori?"

Byron rolls his eyes and tosses a pillow in Shelley's direction, which he easily dodges. He is sensitive about the subject of his personal physician. Though he pays the man handsomely, and keeps him 'round at every moment, he thinks his nervousness to contagion unmans him somewhat. "Perhaps you should fetch Polidori," he says thoughtfully. His countenance has shifted somewhat. There is a devilish sort of delight about him. "Mary, sweet, could you be moved to lay the little man down to sleep? I should think the night's activities will be...unsuitable for him." He winks.

By Christ. Byron is a man of voracious appetite, both of food and women. And men. He has attempted to charm me into his bed, to pull Shelley into dark corners. Shelley finds it quite humorous. He's encouraged me to indulge the baron just once, if only to shut him up. I scolded him soundly for that remark.

"You are a dog, sir. I will not send my son away so that you can--"

Byron chuckles. "My dear, you mistake my intentions. As delighted as I should be to have you and your husband join me in activities of that sort, I am speaking of something entirely 
different. I wish to strike fear into your hearts this rainy night. I will fetch a certain volume I own -- stories of the most frightening nature." He claps his hands together. 'It's settled, then. Mary, put Willmouse to sleep. Shelley, call for Polidori. Perhaps for Claire.” He adds her name as so much of an afterthought that my heart aches for the poor girl. She is waspish and irritable, but she is my sister. She acts like a fool for the baron, but his occasional attentions only fuel this.

"Perhaps Claire should remain abed," I suggest softly. "She has a hysterical nature." Byron nods. Her personality is often an annoyance to him.

I am sure if she knew I've declined an invitation from Byron on her behalf, she would be livid. I am only preventing further heartbreak. She will disbelieve this, I'm assured. I shrug off the thought as I hand my sweet boy off to his nurse. She treats William as a son, and is ever so sweet with him. It does pain me to part with him.

I return to the fireside to find the men, with the addition of Polidori, gathered. Polidori offers me his chair, opting to sit on the floor. Sweet man -- he is infatuated with me, though I cannot fathom why. Byron's handsome face glows red in the flickering firelight. He grins with all his teeth, all but bearing them.

"Thank you for gathering with me on this cold night, children," he intones. Shelley raises an objection to this, and a short argument ensures. Polidori and I exchange a glance. The egos of these men, so fragile! So breakable! When my Shelley is at last assured Byron does not consider him a child, he settles. He sits at my feet and lays his head in my lap. I card my hand through his hair and do not dare point out the irony of his position. In a few short years, little William may be laying his head on Mama's lap and needing her attention. I stifle a snort.

Byron cracks open his volume of horror and reads in a booming voice. He tells the tale of a barber surgeon wandering a castle in death, haunting the ladies who reside there. I'm sure he's 
added in a few details, such as the barber leering at the nobles as they undress, and observing their relations with their husbands. He reads on and on, shouting the words of brave men seeking their fortune, hissing the dialogue of spooks and ghouls, and groaning the last words of a hanged man who promises to haunt his executioners.

After perhaps two hours of his storytelling, he reaches the final tale in the novel. He paints a wonderfully gruesome picture -- a grave-robbing lunatic who beheads a recently deceased man and reanimates it through magic. The head speaks in riddles, but always predicts the truth if one can unravel its words. Eventually, the head predicts the death of the graverobber, who goes mad trying to prevent his demise.

This is perhaps the only story that has chilled me. So haunting! So unnatural! The dead speaking again, their rotting bodies reanimated. The desecration of a grave is an awful thing, but how easily I can picture the pale hands of the graverobber scrabbling at the dirt, prying open the lid of a coffin, cutting into the neck of the dead man. I shiver delightfully.

At last, Byron has finished his volume of horror. "Sufficiently terrified, then?" he challenges.

Polidori nods.

"They were delightful stories," I say. "Chilling."

Byron snaps his fingers, his countenance lighting up. "I have a grand idea! We will each write a ghost story. We will work away at it through this dreadful summer, and present them to one another at summer's end. What say you?"

Percy immediately accepts. He will, he announces, write a tale so hair-raising it will make Byron jump. Polidori offers, somewhat hesitantly, a tale of a vampiric freak risen from the dead. The men turn to me. "Well, Mary?" Shelley asks. "Do you wish to write a ghost story?" 
"I do!" I say. The image of that haunting head is stuck in my mind. If I could write something so horrifying, so interesting, I am sure it would be a great work.

\section{XXX}

After trying in vain to write something ghoulish for several hours, I retire to my bed close to dawn. Shelley is already deeply asleep, his curls splayed out on the pillow like a halo. He does look angelic in his sleep. Much younger than his twenty-three years. I see traces of the mischievous boy who terrorized his sisters in his sleeping visage. I feel so overcome with love for this man, for my dear son, for my sweet daughter in her grave. What a delightful thing, to die of love, I think, before falling into slumber.

He is a student. Of medicine, perhaps, or natural philosophy. He is pale as the flesh of a dead thing. There are deep black rings 'neath his eyes, and his expression is one of deep intensity. He is sweating, his eyes shining. Perhaps he is feverish. He crosses a shadowy room towards a large stone slab. It is lit with brilliant moonlight, so unnaturally bright it pains the eyes.

As he approaches the table, his fevered expression begins to make sense. Lying there is a great, hulking creature the height of two men. Its hands are large and brutal. Its legs are thick as tree trunks and highly muscled. The student's gaze travels up the creature, each detail more horrifying than the last. It is the yellow of old parchment. Its eyes are sunken and closed tightly. Upon closer inspection, its limbs are crudely stitched to its massive torso. It begins to dawn on the student that this monstrous thing is the creation of severed limbs and dead things sewn together. The student stifles a gasp.

The creature's eyes snap open. 
I come awake with a scream. I am cold as the grave and my heart is pounding. Shelley sits up beside me, rubbing the sleep from his eyes. "Mary? What in the world's the matter? Are you alright?"

"I know what I will write," I say.

“Write? What?" He is still sleepy, disoriented.

"I know what I will write for my ghost story."

\section{Late July 1822}

Desolation.

There is only desolation.

\section{XXX}

How does one annihilate a heart? What does a woman, truly shattered, look like? How does the world punish one for their sins in such a complete way?

My heart has been ripped, bleeding and raw, from my breast. His heart rests with Hunt. They plucked it burning from his pyre -- damnable, theatrical thing -- and traded it amongst themselves like some kind of...of trinket. They took a piece of him. Word has it Trelawny keened through the funeral, screamed with sorrow if the gossip is to be believed. I ventured to ask Trelawny if I may have this stolen piece of my husband. If he ever cared for me, I pleaded, please return him to me. Return my Percy.

He shrugged, said he'd passed the heart to Leigh Hunt. I pleaded with Hunt. He refused. The man said I do not grieve Shelley appropriately, that I show no sorrow, and loved him not.

The word is that I did not love my husband. That I did not cherish each moment with him, did not hang on each word he said. As if we had never joined together on the grave of my 
mother, held one another in the dark hours of morning, laughed at japes he made. As if I did not tuck the beloved stubborn curls behind his ears. As if I did not trace his lips with my eyes each time he spoke. As if our child, the only shred of my husband I will ever have, was not a product of love.

We did not have the perfect marriage. His eye wandered. His temper was short. He would often consider himself very ill one moment, and terribly alive the next.

Terribly alive.

He is...he is not. He is not. I loved him with all that I had. I love him more than I could speak. That is the grand problem, perhaps, that I cannot speak. To speak my sorrow would unleash a storm I fear I could not weather. If I voiced, for a single moment, the slaughter of my soul, I would scream. I would scream for years. I would tear the hair from my skull. Drown the son who will never know his father, so that they may share some commonality. I would rip the flesh from my body. I would rend the world in two.

And so, I do not speak. I accept their condolences with a smile. I am a stoic widow. A woman who bears grief as a soldier bears war. Unhappily, but understanding that it is their duty. I wear black, I shake hands, I console poor Jane.

And in my mind, I scream. I scream and hold the pieces of my annihilated heart.

\section{Jane Williams}

\section{4-1825}


Truthfully, she is my sole delight, I write. I hesitate over the sentence, my quill ready to strike it from the page. She is my dearest friend, may be a more suitable line. She is a companion to me in these lonely days, perhaps. I appreciate her company.

I lay the quill down. It rests neatly on the writing desk. The low light of late afternoon is visible through the open window, and there I see her, kneeling in the garden. Her garb is simple -- she is unadorned in finery. Her curls hang about her face, limp with the heat of the day. She is beautiful. I cannot see exactly what she labors over, but I can imagine those dear hands digging for carrots. In my mind's eye, I can see her fingers -- long, delicate, like Shelley's -- grasping 'round the green leaves of a carrot. I imagine her pulling hard at the stubborn stem, tongue poked out in concentration. A dear habit. So childlike.

In a flash, Young Percy dashes to her. "Janey, Janey," he crows, and throws himself into her arms. She tosses a parsnip aside to catch him. Ah, so it was no carrot at all. She twirls my son in a circle, and their laughs entwine. They dance through the rows of vegetables. Young Percy is a sturdy little lad, his legs stocky and his face round. Cherubic. He looks very little like his father, even less so his siblings in their graves. The pale curls, however, are all Shelley.

I see the specters of all those I have lost each time I look upon him. I know Jane does as well, but she speaks less of it. Instead, she weeps in my arms when she thinks I have fallen asleep. I feel her quake against me for hours each night. I shake my head to clear the ghosts away, if only for a moment.

Young Percy takes Jane's hands in his. "Dance with me, Janey," he cries. "Dance with me!"

"That's Ms. Williams to you, little lad," Jane chides. She hides a smile behind her hand. 
“Ms. Williams, then! Dance with me! Join me!” Young Percy leaps and twirls to music that only he can hear. Once, years ago, I imagined that William would grow into his father's legacy. He would be a poet, I had decided. I know not what Young Percy will be. I hesitate to think this far ahead. Then again, I reflect wryly, he has lived longer than any of my children. Young Percy spies me watching them and dashes to the window. "Mama! Are you finished with your writing?" He clambers onto a bucket someone has left beneath the window. "Will you join us? Come play with me and Janey -- oh. Ms. Williams." He rolls his eyes fondly. The gesture is like a blow to my heart. His father used to roll his eyes, bemused, each time he spoke without precision.

My God. Will there be a day where I do not think of Shelley? Where I do not wake up with Jane's tears on my chest, and a feeling that the world has no joy left for me?

"Mama? You look...far off." Young Percy’s face is screwed in an expression of concern. I smile. "I will join you, sweet. Give Mama but a moment, and I will be with you." I return my quill to its inkwell and neatly tuck my papers away. I make up the bed and move a few trinkets to different spots. At last, I walk to the garden. The golden light has cast something of a glow on Jane's pale face. She grins at me, unguarded and sweet.

"Thank you for joining us, Mary," she says softly. "Young Percy wishes us to dance with him."

“Oh, do you now, little lad?” I say. "What do you think, Ms. Williams?” I see a lightning strike of pain cross her face at the mention of Edward's name. "Should we entertain this notion?" “Oh, please, Mama! Please, Janey -- Ms. Williams! The sun will set soon, and I will have to go to sleep! Please dance with me!" 
"Perhaps I will!" I lift my son into my arms -- he is not a light child -- and rock from side to side. "Shall we dance like this?"

“No, Mama! Release me! I will show you!” He squirms from my grip and begins to twirl. He twirls like a dervish in the Orient, his hands thrown wide towards the sky. His little feet turn him in circles, fast and even faster. Laughter flows from his mouth without thought. His existence, I think, is a state of sunshine and joy. The only sorrow he knows is a bedtime he thinks himself too old for. "You must," he cries, as lurches in another rotation, "spin with me! You must twirl!"

"We must twirl," Jane repeats, smiling slyly. "The boy king has spoken."

I stifle a laugh. We throw our arms out to the waning sun, and we spin.

\section{Winter 1825}

"My fairy girl." The words slip from my lips unbidden.

Jane raises her head from the pillow. Her dark curls fan 'round her face like a halo, the way Shelley's did many years ago. My heart aches, a twinge like a bruise handled too forcefully, but the pain fades quickly. "Fairy girl," he muses. "You speak well." She raises a hand to her lips, daintily covering a yawn. She is ever the lady.

The harsh winter sun filters through the panes and casts a chill light on our little room. The room was once Jane's, and I shared a chamber with Young Percy. I have not shared his bed for many months now. He likes his independence, and does not question why Mama and Auntie Jane bed together.

"Good morrow," Jane says. She sits up and stretches, the pale column of her throat thrown carelessly back. How many times now have my lips grazed along that creamy flesh? 
"Good morrow," I return. Young Percy is likely still abed -- he is but six, but displays many of the troublesome and amusing characteristics of adolescence. He would sleep the day away if we let him.

Jane shivers and draws the bedclothes tightly around her. "I take it the day will be frigid," she grouses. She puts on a childish pout, mimicking Young Percy. "I do not like the cold! I tire of this endless chill!"

I roll my eyes fondly. "I would pluck the moon from the sky for you, my dear," I say, "but I cannot command winter to turn to summer. Even for you." I place a kiss on her cheek.

A sly look crosses Jane's face, her lips turning up in a mischievous grin. "Perhaps you cannot change the seasons for me. And perhaps the day will be frigid. But do you know what a chill day demands?"

“I don’t," I say. Jane and her whims! To indulge her brings me joy.

"The best thing one can do on a day like this is to laze about! To idle! To..." She trails off, her eyes twinkling.

“To do what?"

“To keep warm. To stay in bed.” Her grin is so sweet, so devilish, I cannot help but laugh. "And there are many activities one can do to keep warm."

I laugh again. “And what, my dear, do you propose we do for my son? Lock him from the room? 'No, darling, you may not come in today. Your mother is with her lover. Good luck to you!'”

"It's time the lad learned to keep a house," Jane laughs. "He can slave over the stove and chop the wood. Be like your mother! Let the man of the house fend for himself for a day! What would Mrs. Wollstonecraft say?" 
Though she teases, I cannot help but wonder what Mother would think of my life as it is. A woman of nearly twenty-six years, husband and children in the grave, cavorting about with a woman? Raising my son on a diet of poetry and outdoor ramblings, unable to bear the thought of sending him off to a school? Posthumous rumors spread about Mother told tale that she was fiercely jealous with her female friends. That she could not bear the thought of their affections turning to any other than herself. The more salacious ones implied that Mother pursued these girls romantically. I always scoffed at the idea, even decried it, and yet...here I am. Here I stand.

"Mary?" Jane places a soft hand on my cheek. "Where do you go?"

"Where do I--?"

"Your eyes go soft and -- and far away, as if you are in another world. You do not speak. And you look..." Her smile falters. "You look...unbearably sorrowful. What do you see?"

I smile, but I know it does not ring true. "I see...just the past, darling, nothing more. Do not worry yourself for my sake."

Her hand has not left my cheek. "I see Edward in my dreams. Waking or sleeping, I see him. I see him as they found him, bloated and -- and rotted and eaten away. I only wish to say -you are not alone. In seeing the past, that is." She offers a tremulous smile.

We speak of Williams and Shelley near every day. Not just to keep their legacies alive for Young Percy's sake, but for our own. The pain never leaves, even three years since -- since they...drowned. Sir Timothy refuses to let me speak his name in print. In ways, Shelley only exists in our reminiscing. His circle speaks to me rarely, as they still believe me unfeeling in the wake of his death. Even Byron writes less and less. To speak his name is to be assured he exists. Existed. 
The pain has dulled somewhat. It feels less like a knife in my chest each time I speak of him, but it is painful. Exquisitely so. I am sure it always will be. Jane cries less in her sleep, but still she screams Edward's name. The lessening frequency of our bouts of despondency do not comfort me. In a roundabout way, healing feels as if I am betraying him. That I am forgetting him. And this...this thing with Jane -- this dalliance, this affair, this love, even. This feels even more treacherous. There are days I can hardly breathe for the guilt of it all.

"You've done it again," she says softly. "You've gone away."

"I apologize," I murmur. My cheek feels deathly cold, and I realize she has removed her hand. "I do not mean to leave you so often, even if it is not physically."

"I understand," she assures me.

Dear Jane. A rush of sentiment fills my chest, almost chasing the terrible guilt away. It fails to do so, instead shoving it somewhere small, where it may skulk and wait to pounce upon me. Enough of this. Jane is all I see, her beautiful pale skin, her sleep-mussed curls, her dancing eyes. I take her hands in my own. "Perhaps," I say, "perhaps we could stay abed a while longer. Perhaps we could linger.”

She grins, all sorrow forgotten, and throws herself upon me.

1827

The letter falls from my trembling hands. It lands so softly, so inconsequential, on my writing desk. Its contents has chilled me to my core, replaced my blood with ice.

How could she?

Why would...why would she? 
My dear Mary, the letter reads. It has come to my attention that you are summering and wintering with Mrs. Jane Williams. I must admit, I was quite surprised to hear this, given the nature of the remarks she has been spreading through our circle. I considered, then, that you may be unaware. The thought would not leave me. I am dreadfully sorry to write to you this way. Perhaps you do know. Perhaps you have forgiven her. But I must inform you, if you are in fact unaware.

Jane speaks ill of you. She has sent letters to myself and a number of others with dreadful accusations -- that you did not care for your husband, that you speak poorly of him even now. She also has leveled accusations of a...sapphic nature. She has said that you have thrown yourself at her feet and begged for her attention. And for more. I cannot write on the subject any longer. Forgive me, Mary. She has said that you raise Young Percy to disdain his father, and that you despair at her relationship with Thomas Hogg. She has said you decry her little daughter as a bastard.

There is much more she has said, Mary, but I fear for your constitution. I am dreadfully sorry to inform you of this -- assuming, again, you are unaware -- in a letter. It feels unkind.

I hope you and Young Percy are well, Mary.

It cannot be true. Not my fairy girl. My dearest Jane, with whom I have shared a thousand tears and kisses. Who I have held as she screams with sorrow for Edward. Who my child loves more than life itself.

Who I love.

"Mary? Darling, you sit still as a statue. One would think you were formed of marble." Jane has entered the room, unheard in my turbulent state. She places her hands on my shoulders and chuckles. "Though of course you are as well-formed as the statues of--" 
“Why?" I hiss.

"Why?" She removes her hands from my shoulders. "Why what? Are you well, Mary?"

I rise from my writing desk with as much dignity as I can muster. I take the letter in hand and turn to face her. I hold the letter in the air between us, which suddenly seems as vast as a canyon. She speaks not.

"Take it," I say, my voice hard. "Read it."

"If -- if you wish, dear. Did you receive troubling news? Is your father unwell?"

"Read. The. Letter."

She huffs and begins to read. I watch her eyes skim the words and see the exact moment her face blanches. She lets the letter fall to the floor, much as I did only minutes ago.

"I -- I would never -- Mary, you must believe me -- I would never dare -- they are lying --" Her sputters are almost laughable. A cat caught with the family canary in its mouth, still claiming innocence.

"Why?"

“This is a slanderous lie!" she thunders. "I would never speak such words about you! I would never besmirch your--"

"You would not dare speak them," I interrupt softly. "But you would dare to write them. Do not play me for a fool, Jane. I know Shelley was infatuated with you. I know what you did when you thought I was unaware. I knew what you did." The words come out in a growl. I have never spoken with such malice. "I was not cold and unfeeling, you traitorous bitch. I was broken."

There are tears in her eyes. "Mary, you must believe me. Rumors have begun to spread about the nature of our relationship. I had to -- to save myself from them." 
“Then save yourself," I return. "Do so alone."

I turn and, heart shattering, leave her.

\section{Mary Jane and William Godwin, the Ghost of Mary Wollstonecraft}

\section{Summer 1804}

"Your mother was a great woman, Mary. The very best. Do you understand?"

Father grips my arms tightly. His hold is on the razor-thin edge of painful. I stand ramrod straight, hoping I look grave and serious. I only wish to impress him. I look into his eyes steadily, unblinking, and nod. "I understand, Papa."

"Her legacy is of the utmost importance. It is your job to see that it is carried forward. Do you understand what this means?" His tone holds so much intensity. We have had this conversation many times before, and it feels like a play well-rehearsed.

I nod once more. "Yes, Papa. I must continue her work."

He gives a sharp nod, pleased. "And what is her work? Her life's mission?"

I hope he will release me soon. I wish to return to Fanny and our books. He has beckoned me to his study, with its dark wood and austere decorations. I do not like this room. It is so dour. There is no joy here. Not like our little library, with its plush chairs and spots of sunshine.

"Mary. Her work." 
"Oh, yes. Her work is to improve the rights of women everywhere, and to see equality done. And to -- to rebel against the tyranny of government. I must take care to carry on Mother's work in all that I do." No matter the frequency with which I say these words, they feel foriegn in my mouth. Too proper. Too stiff. Unsuitable for a child of my age.

"Yes." He releases me at last, but I stay rigid and mindful of my posture. "And why, Mary, does it fall to you to do this?"

I loathe this part of our little dialogue. Father is ever so unkind to Fanny in these moments. "Because my temperament is suited for it," I mumble. Perhaps he will not disparage my beloved sister. Just once.

"Why?" Father presses. "You are the younger child, after all. Why not your elder sister?"

"Because -- because I am a more confident speaker."

"Mary...come now. You are seven years old, not a child of two. Why is Fanny unsuited to carry on your mother's legacy? You know this." He settles back into his chair, and crosses one leg over the other. He raises his eyebrows.

"Because -- because she is quiet. She shies away from attention." I am no rebel against Father. I just cannot stand to speak poorly of my Fanny. She is so dear to me.

"Mary!" Father thunders. "Enough of this! You know better. Why?"

I sigh, defeated. "Because Fanny is weak-willed, Papa. I am not. I am confident and defend my ideas well. She shies away from confrontation, and intellectual thought. She is a kind girl, and good-natured, but she is no great prodigy. And -- and she is too weak to do the work required." I squirm under Father's gaze.

He grunts. "Acceptable." 
"Papa..." I venture. "Fanny is not...she is not dull, or unkind. Perhaps if you -- I mean to say, if you let her try -- with Mother's legacy -- perhaps she would...she could...impress you. If -if you gave her a fair chance. If you trained her as you train me, I mean to say...she could help. She could assist me! Mother's legacy would...it would be stronger, I think, if two people shared the work."

Father trains his sharp gaze on me. I try not to wither under it. "You may argue, Mary, and defend your ideas. But you may not stammer and stumble as your sister does. You may not snivel and pander to her. Your mother would be disappointed."

Disappointed? He could not have said more cutting words. I do not dare take a breath without thinking of Mother. No one has more knowledge of her than Father. He must be correct, then. "I...I apologize."

Father grunts. "Do not apologize to me, Mary. Apologize to your mother."

I want so badly to take back my words about Fanny. They are not my words, really, but Father's. I only parrot them. Even so, I feel my resolve weakening. Fanny is not worth disappointing Mother, or distracting me from the work of carrying on her legacy. I must do my duty to her. I must. "I am sorry Mother," I say to the air around me.

I can all but feel her scalding disappointment.

\section{2}

“Well, hello! Hello, little girls! I am your new mama. Isn't that just wonderful?"

Fanny looks to me. I look to her. I do not know what to say to this woman. She is plump and plain. Somewhat ugly, to speak the truth. Fanny steps behind me and takes my hand. I am my sister's fierce defender! I will save Papa and Fanny from this stanger. 
I look to Papa. "Who is this woman?" I ask him. "Make her leave us!"

"Mary!" he admonishes. "Be kind!" He drags Fanny away from behind me. "And do not hide behind your sister, Fanny. It doesn't suit a girl of eight."

"Who is she?" I ask again.

Father palms the back of his neck. "Well, girls...this is my wife. Mary Jane."

“Mary?" I cry. "Papa, I am Mary! Mama is Mary!”

"Yes," the interloper trills. "Exactly, darling. I am to be your new mama, and we will be very happy together." She moves from Papa's side and tries to grab me up.

I duck her embrace. "No! You are not my mama! Leave us alone!" I stand with my fists clenched. I will use force if I have to! No one can replace Mary Wollstonecraft! She is the greatest woman in all the world -- Papa says so! This drab woman has no place in our house. She has no place in our hearts, especially not Papa's.

Fanny takes a tentative step forward. "Pleased to make your acquaintance, ma'am," she says softly. "I am sorry for hiding." She sticks out a hand to the pump woman.

The stranger coos and assures Fanny her actions are "perfectly understandable for a girl with no feminine influence." Whatever that may mean. She wraps Fanny up in her doughy arms and seems to squeeze the life out of her! "Aren't you a darling little girl?" she simpers. "Aren't you a sweet little child? Just cherubic, isn't she, William?"

William? Cherubs? So much is happening at once! Fanny is a traitor to me, and this ugly woman has called Papa by his first name. "That's Mr. Godwin to you!” I snarl. "Show my papa respect, or I shall make you leave the house at once!"

Instead of terror, she looks...bemused. Oh, my blood boils. The woman has the audacity to giggle. "Aren’t you a recalcitrant little thing!" she clucks. "Such a temper on such a little girl." 
She holds Fanny tightly to her as she comes toward me. She takes my cheek between her fingers and pinches hard. "Oh, we will get along famously, darling. Just you wait." She pinches my cheek even harder. Her grin is sinister and mean.

I tug away from her and run to Papa. I'm shamed, but feel hot tears welling in my eyes. “Make her leave us, Papa!” I cry. "Make her go away. I do not want a new mama. I only want you and Fanny." Some of the tears leak out, and I quickly knuckle them away. Papa does not like weakness.

"Mary!" Papa says. His tone is all steel and acid. "You will treat my wife with respect, and quit this foolish talk. She will live with us now. And you will have a new brother and sister. You will be civil and kind. Now hug your step-mother!”

Fanny looks to me plaintively from the awful woman's grip. She appears to be melting into her side! "I will not touch her," I say. I mean it to sound strong and powerful, but it comes out a whine.

“Mary, embrace her,” he growls. "This instant!” I can see his face turning red. Veins appear to bulge in his neck. I wonder if he will strike me were I to push him hard enough. He has never done so, but many other papas do. I know I tread on thin, thin ground.

I glare with all I am worth as I step forward and wrap my arms around the terrible woman. She holds me tightly and crushes me to her bosom. She is too soft. I catch Fanny's eye and glare at her. Traitor.

"You will never be my mama," I hiss, low so only this stranger can hear.

"We will see about that, little beast," she returns quietly, and squeezes me even tighter. 


\section{August 1819-April 1820}

I write and write. Day and night, I scribble at my paper until my hands are ink-stained and aching. I pour my pain, my screaming heart, my shrieking mind, into the pages. I write until the skin of my fingers breaks. Until my blood stains the pages as much as the ink does. Good. It is at least proof that I am still alive. That my heart still beats, even when the hearts of my children do not.

Willmouse and $\mathrm{Ca}$, in the grave within months of one another. There are no words for my sorrow. There will never be words. I wrote to my father days after Clara's death, and then again days after William's. They are dead, I wrote. My children, my blood, my darlings. They are dead.

He did not reply for weeks.

At last, a letter came, a ragged, ink-blotted thing, scolding me for mothering bastards, and demanding Shelley settle Father's debt. He also reminded me in no uncertain terms that he had refused communication with me for a reason, and he would not be writing again. Oh, and he supposed he was sorry for my wounded feelings. Shelley saw me open the letter. He saw me read the words, and the tears that slipped unbidden from my eyes.

Oh, he raged when he read Father's words. He blustered and snarled and paced the floors. I only cried quietly. When Shelley had ranted and raved himself to sleep, I left the house, walked a distance, and screamed my lungs raw. I ripped the letter to pieces, scattered it to the wind, and shrieked. I cursed Father. I cursed Mary Jane. I shrieked and sobbed and beat my fists upon the earth.

And then I returned home and slipped into bed beside Shelley. He did not awake once. 
And so I write. I write with the fevered energy of one possessed. It cannot be the hand of the muse moving my quill -- it is something much darker. Some wounded, festering, furious creature.

I write of a virtuous girl, a happy little thing. Mathilda, I name her. She is raised by a distant aunt who shows her no love or affection. She is left to her own devices, and attempts to gain a content and meaningful life. All along, the girl is tortured by the knowledge that her birth caused her mother's death. Her father's greatest sorrow happened the moment Mathilda came into the world. She does not let herself forget this for a moment.

At last, at last her father returns to her one day. He has journeyed far, he explains, and sought to heal his wounds. He has thought of Mathilda each day, he assures her. Her memory has been a balm to him. To see her, sixteen, vibrant, full of life, is his greatest joy.

I write and write of Mathilda's ecstasy. I compose sentence after sentence. She is gleeful, euphoric. She is almost hysterical in her happiness to be with her dear father. I laugh often as I write. It is a sound devoid of joy, a bitter and hollowed-out bark. Oh, this father is a saint. He is a sweet man, and so handsome. He exalts in his daughter's presence, and sweeps her away from her unfeeling aunt. Oh, happy day! Ha.

Each night, when my wrist seizes with pain, and my fingers refuse to grasp the quill any longer, I take to bed. Shelley attempts to soothe me. He composes sorrowful poems, he says, and mourns the children as much as I do. Perhaps, he ponders, he mourns them more. After all, the emotions of a poet run devastatingly deep. I do not respond, except for the crazed laugh that shoots from my lips. He tries to take me to bed. His tender touches arouse nothing in me, and I rebuff him each night. He is decent enough, at least, not to force me. 
I awake to another scalding day. I was haunted by dreams of my children in the night. They screamed my name, and blamed me for their deaths. I take no breakfast, and sit at my writing desk. Shelley creeps around me, murmuring words I do not hear, and eventually takes his leave. I am sure he is taking his pleasure somewhere, with some unwitting damsel of a girl. Good. May he find joy in it.

A vicious smile twists my lips as I write. Mathilda's father suddenly spurns her kisses. He leaves their shared dwelling for hours at a time. She is alone once again. Oh, her misery! She must have done something terrible, offended her father so greatly he cannot bear to look upon her. He does not respond when she speaks. He stares at her when he thinks her attention is elsewhere, and there is great revulsion in his eyes. What has she done wrong? How can she atone? She will do anything! He barks at her to give him peace, and not pester him with this whining.

Oh, she mourns. She cries in the night for the father she has lost. Cut off completely, he has refused communication with her. She knows not why he has done this. Mathilda once again tortures herself for murdering her mother with her birth. Poor, wretched girl!

At last, she can take the silence and the rejection no longer. She is sure she will die for lack of love. She leads her father into the forest one beautiful spring day under the guise of a peaceful stroll. They talk of everything and nothing. For a moment, it seems her loving father has returned to her. Mathilda longs to leap into his embrace and cover him with kisses. Perhaps he has been furious with her flirtation, now long-past, with some potential suitor. Perhaps he has thought her too young for this behavior, and is embarrassed to tell her so! Perhaps it is as simple as this! 
At last, in a scenic glen, she confronts him. What has she done, she demands, to warrant this treatment? There is hope in her tone, but she must be serious. She will die, she says, if he does not tell her how she has affronted him. She begs him.

He snaps. She has badgered him enough! She has worn his resolve to thin shreds! Fine! He will speak of why he looks at her with pain and detestation. She had demanded enough! She will rue the day she asked.

My hand aches 'round the quill. My wrist quivers. There is no time for earthly pains. My children lie in their graves, rotting and alone. If I stop writing for one moment, they will haunt me and I will become a sniveling, wretched thing. I clench my first harder, and write with precision.

Mathilda's father speaks in a biting tone. He has fallen in love with her. His terrible, incestuous attraction has given him cause to hate himself. He dares not speak to her for any length of time, much less look upon her with tenderness. He would die if he could. There is no hope for a sinner like him.

Mathilda balks, horrified, and runs. She sprints away from both her father and her life.

I break in my writing to take mid-day dinner. I can only stomach a few bites of bread and enough water to wet the tongue. I will be sick, I think, if I eat more. Shelley comes home, ambles about the house. He asks to read what I have been writing so furiously at. I decline. He sighs deeply and disappears into our chambers.

\section{XXX}

At last, this cheerless tale is told. I have copied it from the blood-stained scribbles into a neat manuscript. I send it off to Father, a horrible sort of glee filling the pit of my stomach. 
Perhaps he will see through the pitiful words. Mathilda's young death, her self-imposed damnation. Will he see my dismal life in Mathilda's words?

The father she loved desperately and graspingly, whose approval she yearns for, who commits a sin. He, at turns, abandons and betrays his daughter. What will Father think when he reads these words? He may not have committed so grievous an act as lusting for his daughter, but his sins may well be as grave. He has cast me from his life unless it is convenient to him. He did not permit news of Fanny's terrible death to come to me until she had been laid in her grave. He did not comfort me as I experience the worst sorrow one can endure. He loves nothing but money, his silly wife, and Mother's legacy.

Damnable man!

Perhaps he will use the intelligence he has so prided himself on and shake himself from his selfishness. I doubt this. If anything, he will read the words and think my mind depraved. I asked him to find the work a publisher. I am sure he will refuse. Perhaps he will burn it. Nothing could be more amusing

\section{6}

My father is dead.

I know not how to feel. I am no longer young. I hold none of the hate in my heart I once had for the man. At the same time, I do not revere him as a god any longer. William Godwin was nothing but a man. A brilliant, exuberant, iconoclastic, bombastic man...but a man nonetheless. He was a very flawed person. At turns, he could be both loving and desperately unkind. He was so very intelligent and yet knew nothing of emotions or empathy. He was clumsy as a father, but 
educated me flawlessly. A wonderful and terrible man. He ruined my mother's legacy with her posthumous biography, and spent the rest of his living days attempting to revive it. Mother's spectre haunted his every moment, as she haunts mine.

And now he is dead.

Mary Jane lives on, mourning her dead children and grandchildren. She sits quietly these days, not speaking much. I know not how she entertains herself or passes the hours. Perhaps she is quite broken-hearted at Father's death. Perhaps she is relieved. She must no longer compete with a dead woman.

I do not know.

I made sure Father was buried next to mother. I believe he would approve. Young Percy spoke at the funeral. His words were clumsy, I believe, but sincere and sweet. The boy loved his grandfather dearly. I suppose I did as well. Such a complicated man leaves a complicated legacy, but I understand something I did not grasp as a young child: it is not my duty to carry on Father's legacy. Perhaps it is not even my duty to carry on my Mother's. I must carry on my own.

\section{Jane "Claire" Clairmont}

\section{July 281814}

“My dear girl, I don't believe I have ever loved you more!” I press my beloved Jane tightly to my chest. Never was there a dearer girl, a more suitable conspirator. Oh, I squeeze her ever tighter! It is her who has made it possible to run into my dear Shelley's arms! I certainly could not have done this without my sister! 
Jane disentangles herself from my embrace and grins fiercely. There is a frenzied look in her eyes. My sister has always had an aspect of the untamed about her, and it is never clearer in this moment. Her ringlets are wild 'round her face, her cheeks are flushed, and her eyes are fevered. Her breath is quick with excitement. "Oh, Mary," she whispers, "what an adventure we will have. No one may control us any longer." She bounces upon her chair.

"I bid you caution, sister," I giggle. "You will break your seat."

Jane chuckles. She is still for half a moment, but cannot contain herself any longer. She launches herself from her chair and begins to pace my room. "Imagine our adventures! I can wait no longer. Ooh, I'm certain I'll leap from my skin!"

“Patience, patience," I chide. I look over our packed belongings once more. I have ensured our readiness ten times tonight, and I am sure I will do so ten times more. Jane's large trunk contains the bulk of our belongings. Lord knows I had to fight the girl like a wild animal for space in the trunk. She was insistent upon packing most of her clothing, many books, and her various baubles. I thought we'd come to blows when I insisted she leave behind her collection of smooth stones so that I may include some of my own clothing.

"I can no longer have patience. I will never have patience again," Jane says. Her eyes are glassy with excitement. "We needn't have patience any longer. Shelley will spirit us away, and we may do whatever we please. Whatever we please for the rest of our lives." Jane throws herself upon my bed. As soon as she lands, she flies one more 'round the room, pacing like a caged beast. "No one will control us any longer," she repeats. "No one!"

I nod. There is a feeling stirring low in my gut that I am trying to ignore. It seems...it seems that Jane is taking our flight less seriously than she should. I want her to have the correct 
reasoning for coming along. An excellent adventure, of course, but we are fleeing for a reason. Well, I am fleeing for a reason.

To be with my Shelley.

I cannot breathe when he is not near. My brilliant, handsome, valiant beloved! Oh, but I will breathe deeply of that pure air soon enough! We will never be apart again. I dream of our adventures, and our travels all over the continent. What I most anticipate, however, are the simple joys of a life lived together. I cannot wait to simply sleep in his arms. To awake to his breath upon my cheek, to look upon his face as my first sight in the mornings. I look forward to the meals we will share. Smiling over a glass of wine. Linking hands as we read aloud to one another. How beautiful our life will be.

And Jane will fit in it...somehow. I suppose.

"No one may control us any longer," I agree at last. "We will exist as our fellow-creatures in nature do: unhurried, unbidden by any urges save our own wants."

"Oh, what a wonderful life it will be," Jane sighs. "I will be free. At last."

I look into the dark night and let silence settle upon us. I know not what thoughts Jane is lost in. Perhaps she images herself as a fair princess, seized from confinement by a handsome warrior-poet. I know she fancies Shelley. After all, Jane and I are not a year apart, and she is very beautiful. Shelley could have chosen either one of us. I feel lucky that he is enthralled with me. The night is warm and still. Not a cloud covers the moon.

Shelley told us he would draw a carriage up to our dwelling at half-past four. Mary Jane and Father are long asleep, and poor Fanny lies abed. I know not if she sleeps. I feel a twinge of sorrow to know I must leave my sister behind. My selfless Shelley expressed a desire to free her from her "domestic cage," as he said, but it was not to be. Fanny is weak of character, docile as a 
lamb for Father. She is a kind girl, but I believe the loyalty of sisterhood would not win out over her guilty conscience were she knowledgeable of our escape. I sigh.

Shelley bade us to make our peace with our absconding, as it is likely we will never return home again.

Home.

What is the meaning of the word, truly? The houses Father quits again and again, and drags the rest of us along like so much baggage? The bedchambers? I have never felt more at home than I do in front of my dear mother's grave in St. Pancras, and soon we will be far from her. My heart aches to leave my mother's place of repose, but I am sure her spirit will be with me. When I was a girl, Father made sure I understood that it was my duty to carry on Mother's legacy in every action I took. I must act with precision, and consider how Mother would have acted in the situation. Would she have approved? Would she have had a cleverer response? Would she have avoided the action completely?

I am unsure how she would feel about my flight. Jane is all but mad with excitement, and a desire to leave this life of ours behind. I suppose my feelings are more...multifaceted. Jane was not my first pick as companion, but she has done for me what few people would, and risked her neck for my love many a time. She is the one who delivered our notes and enabled us to meet without Father's knowledge. I must love Jane. Truly, I do love her. Her feelings are, perhaps, less refined than mine own. Certainly less refined than Shelley's. He is the most brilliant mind of a generation!

I suppose I will miss Father. He has been the man who has shaped my mind into the fine thing it is today. Without his teaching, I am sure that I would not be so bold as to take my own destiny in hand. His marriage to Mary Jane has softened him, I think, and made his character 
more her own than his. It is shameful, sometimes, to see the way they carry on with one another. I hold no love for the woman. But for Fanny and my darling brothers -- I hold love and compassion, and perhaps even sorrow. I hope one day Father will understand my choice. He cannot stop love.

“Oh, when will he be here!" Jane hisses.

"Soon, sister," I say. "He is a man of his word."

Jane cocks her head. She joins me upon my bed, and smoothes the bedclothes with an idle hand. "He is a man of his word..." she echoes.

"Yes?"

"Well, perhaps our Percy is a man of his word to you and I. Certainly not to poor Harriet...and his children." There is the edge of a grin on her face.

I bite back the stinging words that yearn to spring from my lips. Where to begin with her haughty statement? "Our Percy" indeed! And Harriet! She is no wife to my Shelley. She stifles him, and does not understand his genius. There was a time when I felt great guilt for my attraction to the poet, but I will entertain those feelings no longer. Our love is written in the stars, and I will not question my beloved's choices. His children, however...their innocent faces have always struck a tender nerve buried just beneath my heart. To abandon a child seems...not to speak of strength of character. But no! I will not jump into the rabbit's warren of thought Jane wishes to arouse. As sweet and dear as she is, there is an unsettling maliciousness to her sometimes that gives me pause.

"If Mr. Shelley wishes to have Charles and Ianthe join us, I will raise them happily," I answer at last, my tone prim. "I will happily be their mother and greatest defender." 
Jane can see her barbed comment will find no hooks here, and seems to resolve to leave the subject alone. For now. "Oh, but I cannot wait until our valiant knight arrives and sweeps us away," she muses.

As if her words have summoned him from the void, my ears pick up the sound of a carriage making its way up the cobblestones. "Sister, he arrives," I breathe. My heart thunders in my chest and my hands shake. Am I truly to leave my entire life behind? To sneak away in the night with his lordling and my mercurial sister?

Jane's hands have begun to shake as well, though from near-hysterical excitement. "Here our deliverance arrives!" she cries, then claps her hands over her mouth, stunned at her volume.

"Hush!" I hiss. "Do you wish to wake the household?"

"I am sorry, I am sorry!" she whispers. She springs from the bed and picks up her baggage. It is near-comical to watch her attempt to heft her heavy trunk. Were my heart not attempting to spring from my chest, I would guffaw. "Come, Mary, assist me," she beckons.

I take one handle of her trunk and we move, ungainly, down the steps. Each creak of the wood and groan of the settling house seems ready to give us away. Any instance, Fanny could arise from her chambers, or one of my young brothers. What are you doing with that trunk, you two? I can all but hear Fanny asking. I can see her brow furrowed as she pieces our plot together. Are you running off with the poet? The selfsame man who brandished a pistol and declared he would die if Father did not give you leave to see him? Mary! You are a fool. I must awake Father at once!

My troubled thoughts tangle upon themselves until my breath is all but heaving. At last, we make our way outside of our dwelling.

And there he stands. 
My Shelley, radiant in his joy, resplendent in the night. I let my end of the trunk fall to the street, cringing at its loud report. He does not seem to notice. "My girls! Your carriage awaits you." He sweeps a hand towards the vehicle, all pomp and grandeur. A portly little man -- the carriage-driver, I suppose -- begins to load up Jane's trunk and my various belongings into the carriage.

The reality of what I am doing strikes me. This is the single maddest thing I have ever done. If my poet desires to throw me aside for another dalliance, I will be left in ruins. Jane appears to have none of my trepidation. She throws her arms around Shelley and embraces him with all of her strength. She begins to natter on about our grand adventure. The words come out like a flood. I cannot make out a word of what she says, lost in my own emotions. Shelley gives her a hand into the carriage, which silences her. I can see her happy flush in the moonlight.

Shelley crosses to where I stand, seemingly adhered to the cobbles in front of my home. "Mary, my love, you've said not a word," he says softly. "Are you well?"

"Yes," I breathe. "I am."

He leans down to press a gentle kiss to my lips. "You are white as the snow, my dear. Your eyes are alight. Are you sure you are well? Not having -- second thoughts?"

"No, beloved, no," I assure him. "I promise you!" I throw myself against his chest, tears and laughter mingling. "No, I am so very excited to share my life with you. I only regret what my absence will do to my poor father."

Shelley nods. "Godwin is a proud man, my love, but I promise he will come around. I assure you."

Kind words from a man Father has used as a personal bank, and thrown out his front door while screaming about the corruption of his adolescent daughters. My Percy is so kind, so 
forgiving. He tucks a lock of hair behind my ear. My smile trembles through my tears. "No more than one moment, my darling, and I will be with you." I press a kiss to his hand, and flee into the dark dwelling before he can say a word. I search frantically for quill and parchment, and at last find one of suitable size. I dash off a letter to Father, near-hysteric in its pace. It is filled with Please forgive me and I love him and I will always love you. I entreat him not to be cross with me forever, and to please come to love Shelley as I do. I urge him not to treat Fanny too harshly, nor condemn Jane for her part in our drama. At last, I write, I will return to you soon, Papa. You will always be the first man with a hold on my heart, and I will always respect you. Think fondly of Mother's legacy: I am sure she would approve of our great adventure. With endless love and adoration, your Mary.

I throw down the quill and dash into the summer's night. My tears are no more. Instead, there is only endless excitement for the new life I am to start and the two people I am to share it with.

\section{Spring 1822}

"When shall we tell her, then, Shelley?" Edward asks. "If not now, what time could possibly be suitable for news such as this?"

Shelley gazes into the raging fire, his face unreadable.

I watch Jane Williams watch Shelley. She is unskilled at hiding her feelings -- the look upon her face is terribly tender. Poor poet. The messenger of such evil news. She thinks Shelley bears the world upon his shoulders, and this terrible news is just another added weight. 
For once, Shelley does not turn to Jane when he speaks. "Darling," he says, "you know Claire better than perhaps she knows herself."

It takes a moment to register that he is speaking to me. It has been too long since he has used these words of affection with me. "Yes," I allow.

"You have known the girl since she was a child. You knew Jane well before she ever became our Claire." I still remember the day Claire proudly announced she had found a new name, a name fit for a poetess and lover. How we had laughed with joy. It had seemed to fit her so well.

"I seek your council, my love. I do not wish to keep this from her longer than needed. No mother should suffer this news." His face, still so boyish, is earnest.

I shift Young Percy from one hip to the other. He does not favor his father, save for that selfsame sweet face. There are so many things I wish to say in this moment. I am a mother. I have suffered the news of a dead child three times over. Where was your concern then? Where was this tender care you show for one who has had little contact with her daughter, when I held my children as they died? I breathe deeply. In. Out. We are speaking of Claire's sorrows, not my own. I must not let these unkind thoughts intrude upon my mind any longer.

"Claire has a disposition ill-suited to sorrow," I say.

"Sorrow!" Young Percy echoes happily. "Claire's sorrow!"

Shelley winces at his son's words. "Yes, little lad. Claire's sorrow."

Edward rises from his chair and begins to pace the small sitting room. "Were my child dead, and I was kept from this knowledge, when all those around me were aware, I would be furious. It would multiply the hurt." 
I nod. "This is true. But you are stolid of heart, Mr. Williams. Our Claire is not. Recall you, Shelley, how she used to shriek and howl at the ghost stories Byron would regale us with? How, in God's name, will she take the news that her only child has died?"

We stand in silence for a time, each lost in their thoughts. My heart is like a piece of chipped flint, I suppose. Somehow both fragile and infinitely sharp-edged. My dear niece has died -- my sorrow should be greater, my temperament softer. At times, it feels as if some sort of beast has taken up residence in my breast, making me into this stone-hearted woman who cares not for her sister's sorrow, or her husband's wandering affections. I find it difficult to care for anything these days, save for Young Percy.

Shelley stares once more into the flames, wringing his hands. How, I ponder, can my husband have love left in his heart after the tragedies we have endured? How can he meet each day with a smile and a jape? Why does he not share my icy sorrow? Once again, Jane Williams watches Shelley. The yearning gaze she casts upon him does not move me. Edward continues to pace, his face thoughtful. He is a kind man, intelligent and jovial. I know not if he understands that my husband woos his wife. Perhaps he is like me, the owner of a flinty heart. Perhaps he has learned to live with this, and somehow still finds joy in the world.

Perhaps--

"I am not a fool."

As one, we turn to Claire, standing in the doorway to the sitting room. She is framed by moonlight, her pale skin and dark curls looking for all the world as if they are glowing from within. She takes a faltering step forward, then another. The moonlight follows her. 
"Do you think I do not see the way the four of you look upon me?" she says softly. "Always tracking me with your eyes. Flinching each time I speak." She shakes her head. "I am not a fool. You are obscuring a truth, all of you."

"Claire, darling--" Percy begins, a smile on his lips.

"No," she says neatly. "I will not be swayed by your pretty words."

"Claire, I--" he tries once more.

"No," she says, firmer this time. "What are you hiding from me?"

A beat. There is nothing but silence.

"Sorrow!" Young Percy pipes up. "Claire’s sorrow!"

There is another moment of painful silence. Claire breaks it at last with a bitter laugh. "It appears even the child knows something I do not. What has happened? Has something happened to Byron? To Allegra?"

I tighten my hold on Young Percy. My heart may be a hard one, but this news should not be delivered by any person save for a mother. "Yes, sister. We have been obscuring a truth from you. You are correct, and it was wrong of us. Allegra has died. I--"

Claire lets out a single, choked cry.

It is as if the flint 'round my heart has suddenly cracked away. By God, she is losing her child. In this moment, she is losing her child. I have done this thrice. How can I deliver this news so unfeelingly? What kind of beast have I become? Tears begin to rack my body as I reach for my sister.

She steps away from my touch. Tears stream down her face. "I bid defiance to the dark visitings of misfortune and to the disastrous hauntings of fate. You cannot inflict more than I will 
proudly bear." I know not who she says this to. Her face is resolute, even tear-streaked. "I bid you goodnight."

She turns from the room and leaves.

\section{Lord Byron}

\section{Summer 1816}

"You know, my dear, the world is at your fingertips."

I look up. Byron has entered the sitting room, his dog trailing behind him. “Oh?” I place my book upon my lap. I am surprised to see him inside on this rare sunny day. The men and Claire have been rambling through the hills since early morning. Even little William is outside with his nurse.

"I speak the truth." He sits across from me, gazing out the window. With something other than driving rain to look upon, the view really is quite beautiful.

"I'll play your game, my lord. I am sure you are waiting for me to ask, 'Whatever do you mean?"' I smirk at him.

Byron raises his eyebrows. "You, Mary Shelley, are as clever as you are beautiful."

"Trying to charm me into your bed again, sir? I thought better of you."

He chuckles. The dog lays its head upon Byron's knee, and he strokes its ears absently. "To charm you, yes. Into my bed? Perhaps not." He pauses, a look of great consideration upon his face. “...Yet."

"I ought to run screaming." I cannot help but hide my smile. Byron is a proud man, and a pompous one, but he is a friend to me. 
"I came here with a purpose, believe it or not, Mary. Your husband and I were reading one another's work last night, and he took the liberty of showing me some of your writing. I must say, my dear, you have a gift."

"Why, thank you."

"I mean what I say," he says. "You have a gift for writing that I have not seen in a woman."

I grin.

"There are many things that I could teach you...if you allowed me."

“About writing?” I ask.

Byron makes a great show of mulling my words over. At length, he smirks, "Among other things."

I flee from the room, laughing all the way.

\section{XXX}

It is night, and rain pounds against the roof once again. We are gathered in the sitting room, as we have done each night this summer. This strange, terrible weather has forced a routine upon us, but it is not an unhappy one. Shelley is in excellent spirits, invigorated from his ramble in the wilderness.

I look upon my dear friends and cannot help but smile. Polidori, who eyes me with poorly veiled admiration. Shelley, speaking animatedly to Byron, who chuckles in response. Claire plays with little William upon the floor.

And I sit, contented, in happy repose. I cannot help but feel Byron is correct. The world is at my fingertips. These people, this work -- this is my world. 


\section{4}

FAMED POET DIES IN GREECE.

I hold the newspaper in hands that no longer tremble. Perhaps I can no longer be moved by sorrow.

Byron has died.

I sigh. We have kept up correspondence for years, but his letters had slowed. I had thought Byron was occupied with his war, and had little time for old friends. Always the rogue. Always the gallant charging in to rescue the troubled and play the hero. Foolish, foolish Byron. I want to mourn. I want to lay down and weep, but I cannot seem to. Perhaps this was inevitable. The paper claims Byron could have toppled the Ottomans bare-handed, that he would have been crowned King of Greece. I can see him ruling benevolently, so like the characters in his poems. Much like Shelley, he wrote his role into the world. The flirtatious rascal, handsome aristocrat, hero to the oppressed. He played his parts well, I will grant him that.

He was my friend.

I fold the newspaper neatly and let it rest upon my writing desk. His death was not grand. He died, sickened and alone, because of some foolish doctor. How much death must I endure? My husband, my children, my friends. And why did he throw himself into war as if it were sport? His beliefs were staunch, but...now he is dead.

I turn to look upon the room. The pale light of early dawn touches upon the sleeping forms of Jane and Young Percy. He is curled into her body like a kitten. I cross the room and stroke his dear cheek. Jane cracks an eye and smiles.

Byron told me many years ago, when I was but twenty-two, that I was a woman of talent and potential. That the world hung at my fingertips. I return Jane's smile. The world is different 
now than I had ever anticipated. My family is small and fragile. My heart is a jagged, broken thing. My days of adventure are past. And yet...I take Jane's hand and squeeze. I still exist in the world.

If only it were less painful to do so.

END 


\section{Bibliography}

Bugg, John. “"Master of Their Language': Education and Exile in Mary Shelley's Frankenstein." Huntington Library Quarterly, vol. 68, no. 4, 2005, pp. 655-666. JSTOR, www.jstor.org/stable/10.1525/hlq.2005.68.4.655. Accessed 26 Feb. 2021.

Bunnell, Charlene E. “'Mathilda': Mary Shelley's Romantic Tragedy.” Keats-Shelley Journal, vol. 46, 1997, pp. 75-96. JSTOR, www.jstor.org/stable/30210369. Accessed 26 Feb. 2021.

Burriss, Eli Edward. "The Classical Culture of Percy Bysshe Shelley." The Classical Journal, vol. 21, no. 5, 1926, pp. 344-354. JSTOR, www.jstor.org/stable/3289170. Accessed 26 Feb. 2021.

Crook, Nora. "Fourteen New Letters by Mary Shelley.” Keats-Shelley Journal, vol. 62, 2013, pp. 37-61. JSTOR, www.jstor.org/stable/24396079. Accessed 26 Feb. 2021.

Gordon, C. (2016). Romantic outlaws: The extraordinary lives of Mary Wollstonecraft \& Mary Shelley. London: Windmill Books.

London, Bette. "Mary Shelley, Frankenstein, and the Spectacle of Masculinity." PMLA, vol. 108, no. 2, 1993, pp. 253-267. JSTOR, www.jstor.org/stable/462596. Accessed 26 Feb. 2021. 
Lovell, Ernest J. "Byron and Mary Shelley.” Keats-Shelley Journal, vol. 2, 1953, pp. 35-49. JSTOR, www.jstor.org/stable/30212479. Accessed 26 Feb. 2021.

Nitchie, Elizabeth. “Mary Shelley, Traveler.” Keats-Shelley Journal, vol. 10, 1961, pp. $29-42$. JSTOR, www.jstor.org/stable/30210085. Accessed 26 Feb. 2021.

Phillips, Bill. "Frankenstein and Mary Shelley's 'Wet Ungenial Summer." Atlantis, vol. 28, no. 2, 2006, pp. 59-68. JSTOR, www.jstor.org/stable/41055247. Accessed 26 Feb. 2021.

Reef, C. (2018). Mary Shelley: The Strange True Tale of Frankenstein's Creator. Houghton Mifflin Harcourt Trade \& Reference.

Sampson, Fiona. In Search of Mary Shelley. Pegasus Books, 2019.

Shelley, Mary Wollstonecraft, and Susan J. Wolfson. Mary Wollstonecraft Shelley's

Frankenstein, or, The Modern Prometheus. Pearson Longman, 2007.

Shelley, Mary Wollstonecraft, and Hugh J. Luke. The Last Man. University of Nebraska Press, 2006.

Shelley, Mary, et al. Mathilda. L.J. Veen Klassiek, 2017.

Sheridan, Claire. "Anti-Social Sociability: Mary Shelley and the Posthumous 'Pisa Gang."” Studies in Romanticism, vol. 52, no. 3, 2013, pp. 415-435. JSTOR, www.jstor.org/stable/24247339. Accessed 26 Feb. 2021. 
Sussman, Charlotte. "Daughter of the Revolution: Mary Shelley in Our Times." Journal for Early Modern Cultural Studies, vol. 4, no. 1, 2004, pp. 158-186. JSTOR, www.jstor.org/stable/27793781. Accessed 26 Feb. 2021

\section{Mary: A Companion Piece}

Mary is a creative thesis told in first-person vignettes spaced throughout Mary Wollstonecraft Shelley's entire life. The work seeks to function as a creative biography, fictionalized but exploring the very real and impactful interpersonal relationships she held dear. Mary Shelley was an incredibly multifaceted person. She was at turns daring and iconoclastic, reserved and private, outgoing and adventurous, deeply depressed and bitter. She worked through much of her personal trauma and turmoil in her novels. She had trauma in spades. Three of her four children died young. Her mother died giving birth to her. Her beloved elder sister committed suicide. Her husband drowned, leaving her a single mother for the majority of her life.

Mary Shelley is arguably most known for being the author of Frankenstien, and the wife of famed Romantic poet Percy Shelley. I sought to understand her as more than that. Through extensive biographical research and study of her novels, I feel that I got to know Mary Shelley as a near-tangible person. Though her work was largely fictional, she explored many aspects of her daily life within them. For example, a portrait of her friend and famed poet Lord Byron is provided as Lord Raymond in The Last Man. Her feelings of abandonment and alienation from her father is explored in Mathilda. I desired to write as she did: to probe and inspect the real within the context of fiction. Through the fictionalized perspective of Shelley herself, I wrote key events in her life: the death of her husband, her suspected sapphic affair with friend Jane Williams, her meeting with her much-despised step-mother. 
The writing process was incredibly illuminating for me. I found it enriching and all but addictive. I have been a disciple of the Romantics since I was introduced to them at seventeen. That said, I have been influenced much more by William Wordsworth, W.B. Yeats, and Percy Shelley than the female writers of the day. Before I began to engage in my thesis, I knew relatively little about Mary Shelley. I found her to be defined by her relationship to her husband, as many scholars do. It felt important, however, to push myself into unfamiliar territory. To write about a woman shrouded in mystery to me, and amplify the life story of a female author. As I began my research, I knew I had made the right decision.

Mary Shelley lived an incredible life. She experienced unimaginable tragedy, invented one of the most popular genres of today, and ran away with a married father of two at just sixteen. Her life is simply rife with writing material.

I was struck with how much Shelley took a backseat in her own life. Though she had moments of dauntlessness, she was in many ways an actor in other peoples' stories. She chose to fade into the background on purpose, it seemed, often avoiding direct confrontation. When signs pointed to Percy Shelley having multiple affairs, she was cold to him and shrugged off his advances, but never confronted him.

To "get to know" my fictional version of Shelley, I explored her relationships with others. It seemed, to me, what she may have wanted. I wanted to use first-person person perspective to give my "character" some agency, and ability to tell her own story. I selected six living people to traverse through Shelley's life: her husband, Percy Shelley; her step-sister, Jane "Claire" Clairmont; her step-mother and father Mary Jane and William Godwin; her life-long friend, Lord Byron; and her friend and suspected lover Jane Williams. Lastly, I chose to weave the proverbial ghost of her mother, Mary Wollestonecraft, throughout each section of vignettes. 
To quote Mary Shelley herself, "The memory of my mother has always been the pride and delight of my life."

I sought to contribute to my discourse community of both Romanticism and fiction.

Every historical biographer engages in a type of fiction -- I suppose I chose to take that a little more literally. This project has been a "pride and delight" to me, and I am incredibly proud to present it. 